\title{
Probiotic effect in vivo of Roseobacter strain 27-4 against Vibrio (Listonella) anguillarum infections in turbot (Scophthalmus maximus L.) larvae
}

Miquel Planas ${ }^{1}$, María Pérez-Lorenzo ${ }^{1}$, Mette Hjelm², Lone Gram², Ingrid Uglenes Fiksdal $^{3}$, Øivind Bergh ${ }^{3}$ and José Pintado ${ }^{1}$

1. Instituto de Investigaciones Marinas (CSIC), Eduardo Cabello 6, 36208 Vigo, Galicia, Spain

2. Danish Institute for Fisheries Research, Department of Seafood Research, Søltofts Plads, c/o Technical University of Denmark bldg 221, DK-2800 Kgs. Lyngby, Denmark

${ }^{3}$. Institute of Marine Research, PO Box 1870, N-5817, Bergen, Norway

*corresponding author

phone: +34986214457

fax: +34986292762

e-mail: mplanas@iim.csic.es

Keywords: Larval rearing, probiotic, Roseobacter 27-4, Vibrio anguillarum, rotifer, turbot larvae, Scophthalmus maximus 


\section{Abstract}

The purpose of this study was to evaluate the probiotic effect of the marine bacterium Roseobacter strain 27-4 in turbot larvae infected with the pathogen Vibrio (Listonella) anguillarum. Initial trials demonstrated that cells of Roseobacter were not harmful to larvae whereas, large amounts of bacterial culture supernatant caused rapid mortality $(70 \%$ at day 10 compared to $20 \%$ in the control). A similar high mortality was, however, also seen, when sterile marine broth was added to the larvae. Presumably both types of medium enhanced growth of opportunistic pathogens. In subsequent trials, both a pathogen, Vibrio anguillarum, and the probiont, Roseobacter strain 27-4, were delivered to the larvae bioencapsulated in rotifers. Accumulated mortality of Vibrio infected larvae increased to 80-90\% over 10 days, whereas, mortality in non-infected controls was significantly lower (60-70\%). Feeding larvae with rotifers enriched with Roseobacter 27-4 parallel to V. anguillarum infection, brought the accumulated mortality to the level of control indicating a clear in vivo effect. Roseobacter 274 could be detected in larvae both by agar plating and by immunohistochemistry, being located in the gastrointestinal lumen, and apparently did not colonise the larval gut and intestinal epithelium. Plate counts decreased when enriched feed was no longer added, suggesting that the probiont, Roseobacter $27-4$, should be supplied repeatedly to exert its positive effect. 


\section{Introduction}

Probiotics have been defined by WHO/FAO (2001) as "live microorganisms which when administered in adequate amounts, confer a health benefit on the host". The use of probiotics has emerged as a potential tool in the reduction of mortalities in the rearing of aquatic organisms (Ringø and Gatesoupe, 1998; Gatesoupe, 1999; Gómez-Gil et al. 2000; Verschuere et al. 2000; Gram and Ringø, 2005). In fish, probiotics have been studied in the prevention or reduction of disease outbreaks in larvae, fry or adults (Kozasa, 1986; Gatesoupe, 1999; Austin et al. 1995; Gildberg et al. 1997; Gram et al. 1999).

The development of the intestinal microbiota in marine fish larvae depends basically on the bacteria colonising in the live prey (in larviculture, mainly rotifers and Artemia) and, to a lesser extend, the rearing water (Nicolas et al. 1989; Munro et al. 1994; Bergh, 1995; Blanch et al. 1997; Grisez et al. 1997; Reitan et al. 1998). Consequently, attention has been focused on the delivery of bacterial additives or bacteria cells to live food as a vehicle for introducing beneficial bacteria to the fish larvae. Several studies have been conducted on turbot (Scophthalmus maximus) larvae due to the economic importance of this fish. The effects of commercially available lactic acid bacteria, including extracts of terrestrial lactic acid bacteria or live bacteria additives, were tested with varying results (Gatesoupe 1991, 1999; García de la Banda et al. 1992). Also, probiotic candidates have been selected among isolate strains from commercial hatcheries (Gatesoupe, 1997; Huys et al. 2001; Hjelm et al, 2004a,b).

We recently isolated bacteria antagonising fish larval pathogens from a turbot hatchery in Spain and the most prominent among the antagonists strains were identified as Roseobacter (Hjelm et al. 2004a,b). Roseobacter species belong to the so-called Roseobacter clade that are very important members of the procaryotic communities of marine environments (Selje et al. 2004) where they are believed play a major role in sulphur cycling (Moran et al. 2003). Roseobacter is typical of the marine environment (Shiba, 1991) and have been isolated from green seaweed (Shiba, 1992), marine aggregates (marine snow particles) (Bano and Hollibaug. 2002) and dinoflagellates (Töbe et al. 2001). Ruiz-Ponte et al. (1998) described $R$. gallaeciensis and later demonstrated that addition to tank water of cell extracts from cultures at particular cell densities enhanced survival of scallop larvae (Ruiz-Ponte et al. 1999). A member of the Roseobacter group was at one point associated with disease in juvenile oysters 
(Boettcher et al. 2000). However, this strain was later grouped as a new genus and species Roseimarina crassostreae (Boettcher 2002).

From the screening performed by Hjelm et al. (2004a) on different groups of bacteria for inhibitory activity in vitro, Roseobacter $27-4$ was selected as the most promising candidate probiotic. This strain showed $99.1 \%$ alignment with R. gallaeciensis (Hjelm et al. 2004a). Strain 27-4 did not oxidise glucose and it differed from the type description of $R$. gallaeciensis (Ruiz- Ponte et al. 1998). In our study, the in vivo ability of Roseobacter 27-4 to protect turbot larvae by the pathogenic strain Vibrio anguillarum 90-11-287 serotype O1 was evaluated. The strain was found to be promising as fish larvae probiotic.

It is known that Roseobacter strain 27-4 enhances survival of egg yolk sac larvae and is highly inhibitory to Vibrio species (Hjelm et al. 2004a). However, its effect has not been studied in model challenge trials. The aim of our work was to study the probiotic effect of the bacteria Roseobacter strain 27-4 in turbot larvae infected with the pathogen Vibrio anguillarum (Skov et al. 1995). Both bacteria were delivered to the larvae bioencapsulated in rotifers. Potential side effects of Roseobacter 27-4 (both bacteria cells and supernatant of bacteria cultures) to turbot larvae was investigated prior to the determination of the probiotic effect.

\section{Materials and methods}

\section{Bacterial strains}

Roseobacter 27-4 strain was isolated from the tank walls in healthy rearings from a turbot hatchery (Stolt Sea Farm) in Galicia (Nothwest Spain) and identified by Hjelm et al. (2004a). The strains were kept at $-80^{\circ} \mathrm{C}$ in TSB (Oxoid CM129) $\left(30 \mathrm{~g}^{-1}\right)$ with glucose $\left(5 \mathrm{~g} \mathrm{l}^{-1}\right)$, skimmed milk $\left(20 \mathrm{~g}^{-1}\right)$ and glycerol $\left(40 \mathrm{~g} \mathrm{l}^{-1}\right)$. The strain Vibrio (Listonella) anguillarum 9011-287 serotype $\mathrm{O} 1$ was used as the target organism. The strain was isolated from rainbow trout (Skov et al. 1995) and obtained from K. Pedersen (Royal Veterinary and Agricultural University, Copenhagen, Denmark). 


\section{Bacterial culture and preparation of the inocula}

Vibrio anguillarum was grown for 24 hours in $10 \mathrm{ml}$ of Marine Broth (MB, Difco, 2216) on a rotary shaker at $200 \mathrm{rpm}$ and $22^{\circ} \mathrm{C}$. Culture $(1 \mathrm{ml})$ was added to a flask with $100 \mathrm{ml}$ of $\mathrm{MB}$, grown for 24 hours, and subcultured twice under the same conditions. Growth was monitored by optical density $(700 \mathrm{~nm})$ and by plate counting (reference!!!!!!).

Roseobacter 27-4 was cultured according to Hjelm et al. (2004a). Bacteria were pre-cultured in 3-4 $\mathrm{ml}$ of $\mathrm{MB}$ and incubated at $20^{\circ} \mathrm{C}$ for three days in the dark and stagnant aerobic conditions. Culture $(1 \mathrm{ml})$ was used to inoculate a 11 flask with $100 \mathrm{ml}$ of MB. After two days, bacteria were harvested by centrifugation at 2,500 x $\mathrm{g}$ for $15 \mathrm{~min}$ and resuspended in $100 \mathrm{ml}$ sterile seawater. The concentration was verified by serial dilutions in sea water and plating on Marine Agar (Difco). These conditions ensured a bacterial concentration of $5 \times 10^{8}$ to $1 \times 10^{9} \mathrm{cfu} \mathrm{ml}^{-1}$. When Roseobacter $27-4$ was added to the water of the larval tanks, the bacteria were centrifuged and washed as described. However, when Roseobacter 27-4 added to the water of the rotifer enrichment, the bacteria were added with the culture supernatant.

\section{Rotifer culture and bioencapsulation of bacteria}

Rotifers (Brachionus plicatilis) were cultured on baker's yeast and subsequently enriched (200 rotifers $\left.\mathrm{ml}^{-1}\right)$ on Isochrysis galbana $\left(2 \times 10^{6}\right.$ cells $\left.\mathrm{ml}^{-1}\right)$ for $24 \mathrm{~h}$. Two types of bioencapsulation were carried out. For bioencapsulation of $V$. anguillarum (Rotifer-V): The rotifers $\left(200\right.$ rotifers $\left.\mathrm{mL}^{-1}\right)$ were enriched on Isochrysis galbana $\left(2 \times 10^{6}\right.$ cells ml $\left.^{-1}\right)$ for $24 \mathrm{~h}$ in 10-20 1 tanks at $23^{\circ} \mathrm{C}$. Rotifers were then filtered (30 $\mu \mathrm{m}$ Nylon mesh), washed and

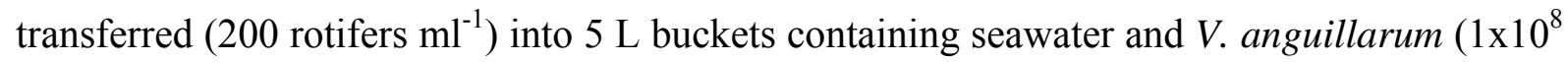
$\mathrm{cfu} \mathrm{ml}^{-1}$ ). The rotifers were maintained in this bacterial suspension for 3 hours and filtered, washed and delivered to turbot larvae.

For bioencapsulation of Roseobacter 27-4 (Rotifer-R), rotifers (200 rotifers $\mathrm{ml}^{-1}$ ) were enriched on Isochrysis $\left(4 \times 10^{6}\right.$ cells $\left.\mathrm{ml}^{-1}\right)$ and Roseobacter $\left(10^{7} \mathrm{cfu} \mathrm{ml}^{-1}\right)$ for $24 \mathrm{~h}$ in $10 \mathrm{~L}$ tanks at $23^{\circ} \mathrm{C}$. Rotifers were then filtered, washed with seawater and delivered to the larvae. 


\section{Turbot larval rearing}

Newly hatched larvae (day 0) of turbot were obtained from Stolt Sea Farm (Merexo, Galicia,

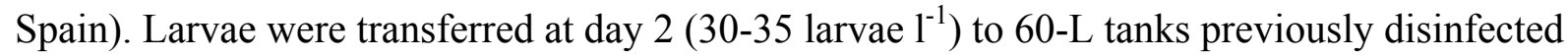
with Dismozon Pur (Bode) $(1 \%, 4 \mathrm{~h})$. The temperature was progressively raised from 15 to $18{ }^{\circ} \mathrm{C}$ during the following 3 days, the water of the tanks was moderately aerated $(>90 \%$ oxygen saturation) and light (day light provided by fluorescent lamps) intensity at the surface of the larval tanks was adjusted to $3.5 \mu \mathrm{E} . \mathrm{sec}^{-1} . \mathrm{m}^{-2}$. The larvae were fed on enriched rotifers from day 3 until day 10. For the different experimental trials, the larvae were fed on alternate days with enriched rotifers with Roseobacter 27-4 or V. anguillarum. The density of rotifers was adjusted daily (3-5 rotifers $\mathrm{ml}^{-1}$ ) and the water of the rearing tanks was partially (30-40 $\%$ ) changed every 2 days from first feeding with a subsequent addition of $2.5 \mathrm{~L}$ of Isochrysis galbana culture $\left(2 \times 10^{5}\right.$ cells $\left.\mathrm{ml}^{-1}\right)$. The bottom of the tanks was siphoned daily to remove and count dead larvae. All the trials were conducted in duplicate. Samples of larvae and/or water were taken for microbiological analyses. Dry weights of larvae were obtained at the end of the experiments after collecting 100 larvae from each tank on $150 \mu \mathrm{m}$ mesh, washing with tap water and drying at $60^{\circ} \mathrm{C}$ for $48 \mathrm{~h}$. A total of three trials were carried out with turbot larvae.

\section{Challenge A: Innocuous effect of Roseobacter 27-4 for turbot larvae}

Hjelm et al. (2004a) demonstrated that Roseobacter strain 27-4 was not harmful to egg yolk sac larvae. However, a preliminary trial was carried out to determine whether Roseobacter was harmful to the turbot larvae at the feeding stage. The trial was carried out in duplicate in eight 60 -L tanks with four treatments. In treatment $\mathrm{C}$ (control), larvae were reared as described above. In treatment SR (single addition of Roseobacter), the larvae were reared as controls and $100 \mathrm{ml}$ of bacterial cells re-suspended in sterile seawater were delivered $\left(10^{6} \mathrm{cfu}\right.$ $\mathrm{ml}^{-1}$ ) to the water of the larval rearing tanks at mouth opening (day 3). A continuous addition of Roseobacter 27-4 (CR) was similar to the SR treatment, except that bacterial cell suspension $\left(10^{6} \mathrm{cfu} \mathrm{ml}^{-1}\right)$ was added to the water of the larval tanks at days 3,5 and 7 . In the last treatment $\left(\mathrm{CS}_{100}\right)$, a continuous addition of $100 \mathrm{ml}$ Roseobacter free culture supernatant was added to the water of the larval tanks at days 3,5 and 7 .

\section{Challenge B: Effect of Roseobacter 27-4 supernatant or Marine Broth}


Challenge A demonstrated that the culture supernatant of Roseobacter strain 27-4 was toxic to turbot larvae, and the following treatments were applied to asses the effects of marine broth and the supernatant of Roseobacter 27-4 cultures on larvae. The control (C) larvae were reared as described above. In treatment MB, larvae were reared as controls with the addition of $100 \mathrm{ml}$ of Marine Broth to the water of the larval rearing tanks at days 3, 5 and 7 . The treatment described above $\mathrm{CS}_{100}$ was repeated and paralleled by a similar treatment $\mathrm{CS}_{5}$ in which larvae were reared as controls with the addition of $5 \mathrm{ml}$ of bacteria-free supernatant of Roseobacter culture to the water of the larval rearing tanks at days 3, 5 and 7.

\section{Challenge C: Probiotic effect of Roseobacter 27-4 against V. anguillarum}

\section{Microbiological methods}

Samples from larvae, rotifer and water were taken under aseptic conditions during the trials. Ten larvae or 400 rotifers were separated using a $250 \mu \mathrm{m}$ or $30 \mu \mathrm{m}$ Nylon mesh, respectively. Larvae were anaesthetised with 3-Aminobenzoic acid ethyl ester (concentration!MS22, Sigma). Larvae and rotifer were washed with sterile seawater and homogenised. Processed samples were serially diluted in seawater, plated on Marine Agar (MA, Difco 2216) and incubated for 3 days at $20^{\circ} \mathrm{C}$ in the dark. Plates with 30 to 300 colonies were counted. Roseobacter 27-4 colonies were identified by their dark brown pigmentation and confirmed by absence of growth on TSA plates (Oxoid CM131) (Hjelm et al. 2004a). For Vibrionaceae 
counting, appropriate dilutions were replica-plated from MA onto TCBS (Cultimed 413817), incubated one day at $20^{\circ} \mathrm{C}$ and colonies were counted. Vibrio anguillarum colonies were recognized and verified using the agglutination test MONO-VA (Bionor, Norway).

\section{Immunohistochemistry}

The primary antiserum was polyclonal rabbit antiserum against Roseobacter 27-4. Vaccines were produced by cultivation of Roseobacter 27-4 in filtered, autoclaved MB for 1-3 days. The culture was treated with formalin at $0.5 \%$ for minimum 3 hours and the cells harvested by centrifugation at $5000 \mathrm{~g}$ for $10 \mathrm{~min}$. The cells were washed twice with phosphate buffered saline (PBS, Oxoid) and re-suspended to a density of $1-4 \times 10^{9}$ cells $\mathrm{ml}^{-1}$. The vaccine was stored at $-20^{\circ} \mathrm{C}$ until used. A rabbit was vaccinated repeatedly by 3 intravenous injections per week of bacterial cells. The doses were from $0.1 \mathrm{ml}$ at the start, increasing gradually up to 1.0 $\mathrm{ml}$ after 3 weeks. In the $4^{\text {th }}$ week a booster of $1.0 \mathrm{ml}$ was given, and in week 5 blood were collected and serum separated. The antiserum was tested for cross-reaction against related species by immuno colony blotting, and adsorbed with cross-reacting species. The serum was stored at $-20^{\circ} \mathrm{C}$. An antiserum against Vibrio anguillarum, kindly provided by Dr. Jens Laurits Larsen was also used as primary antibody.

The immunohistochemical protocol was modified from Evensen \& Rimstad (1997) and Bergh et al. (1997). Turbot larvae were fixed in neutral phosphate-buffered 3.7\% formaldehyde, and kept until processing. The larvae were dehydrated through a graded ethanol series and embedded in paraffin. Sections, approximately $3 \mu \mathrm{m}$ thick were cut on a Reichert-Jung Biocut, incubated for $30 \mathrm{~min}$ at $56^{\circ} \mathrm{C}$, dewaxed in xylene, rehydrated through a graded ethanol series $(100 \%$, Øivind check this $96 \%, 70 \%, 50 \%)$, and brought to distilled water. Nonspecific antibody binding sites were blocked by covering the sections with a solution of $5 \%$ bovine serum albumin (BSA, Sigma Co., London, UK) in Tris-buffered saline (TBS, ph 7.4) for 20 min. The solution was blotted off the slides and the primary rabbit antiserum was incubated at a dilution of 1:900 in 2.5\% BSA in TBS for 30 minutes. After washing for $5 \mathrm{~min}$. in TBS, the secondary antibody, biotinylated goat anti-rabbit immunoglobulin, diluted $1: 300$ in $2.5 \%$ BSA in TBS (Dakopatts, Glostrup, Denmark) was added and incubated at room temperature for 30 min. After washing in TBS, streptavidin alkaline phosphate complex was added, and incubated for $30 \mathrm{~min}$. After washing, New Fuchsin Chromogen (K698, Dako, CA, US) with 1 $\mathrm{mM}$ levamisole (Sigma) as inhibitor in TBS was added and allowed to develop for $5 \mathrm{~min}$. 
After washing in tap water, sections were counterstained with Mayer's haematoxylin and mounted in an aqueous mounting medium (Aquamount, BHD Laboratory Supplies, UK). All incubations were performed at room temperature (approximately $20^{\circ} \mathrm{C}$ ) in a humidity chamber. Tissue sections from larvae not exposed to Roseobacter 27-4, and exposed larvae were incubated with immune and nonimmune (normal rabbit serum) as controls.

\section{Statistical analyses}

Differences in final survivals and weights of larval challenges were analysed using one-way analysis of variance (ANOVA) and Student-Newman-Keuls multiple range test at 5\% level of significance. Survival data were previously transformed to arc sin (square root).

\section{Results}

\section{Challenge A: Innocuous effect of Roseobacter 27-4 for turbot larvae}

Single (SR) or repeated (CR) delivery of Roseobacter to the water of the rearing tanks was not detrimental to turbot larvae and the patterns of accumulated mortality were identical to that of controls (Figure 1). However, a significantly higher mortality occurred from day 2 when the larvae were exposed to Roseobacter culture supernatant (ANOVA: $p=0.035$; SNK test: $\mathrm{p}>0.05)$.

The level of culturable bacteria in the water was constant, at approx. $10^{6}-10^{7} \mathrm{cfu} \mathrm{ml}^{-1}$ (Table 1). In the larvae, the number of culturable bacteria increased progressively from $10^{3} \mathrm{cfu} \mathrm{ml}^{-1}$ at day 3 (first feeding day) up to $10^{5}-10^{6} \mathrm{cfu} \mathrm{m}^{-1}$ at day 8 . A single addition of Roseobacter 27-4 kept concentration constant in values around $10^{6} \mathrm{cfu} \mathrm{ml}^{-1}$ from day 3 to day 5 , being the predominant bacteria in water. After day 5, Roseobacter 27-4 concentration diminished constantly, reaching $10^{4} \mathrm{cfu} \mathrm{ml}^{-1}$ at day 9. Repeated addition of Roseobacter 27-4 resulted in maintained levels between $10^{6}$ and $10^{7} \mathrm{cfu} \mathrm{ml}^{-1}$. After day 8 , the concentration diminished

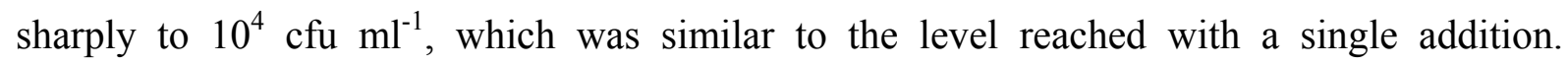
Roseobacter 27-4 was detected in larvae at day 6 in similar concentration $\left(10^{2}\right.$ cfu larvae $\left.^{-1}\right)$ in 
both challenges, decreasing slightly at day 8 with single addition and increasing significantly up to $10^{4}$ cfu larvae ${ }^{-1}$ with repeated addition.

\section{Challenge B: Effect for larvae of Roseobacter 27-4 supernatant in water}

To elucidate the cause of the mortalities observed when culture supernatant was added to the rearing tank (challenge A), a challenge was performed by testing the addition of the supernatant and the bacteria culture medium (Marine Broth). The addition of $100 \mathrm{ml}$ marine broth $(\mathrm{MB})$ or $100 \mathrm{ml}$ of Roseobacter supernatant $\left(\mathrm{CS}_{100}\right)$ reduced the survival and the growth of turbot larvae drastically. In contrast, growth and survival in larvae submitted to the low concentration of Roseobacter supernatant $\left(\mathrm{CS}_{5}\right)$ was high, similar to those in control tanks. The pattern of accumulated mortalities show that the highest mortalities in treatments MB and $\mathrm{CS}_{100}$ occurred between days 5 and 6 post hatching, just after the second delivery at day 5 (Figure 2).

At day 4, the total bacterial numbers in the rearing water in controls and $\mathrm{CS}_{5}$ samples were about one $\log$ unit lower than in $\mathrm{MB}$ and $\mathrm{CS}_{100}$ treated samples. In addition, an ominous turbidity appeared in the tanks submitted to these treatments. Total concentration of Vibrionaceae was higher $\left(10^{5}-10^{6} \mathrm{cfu} \mathrm{m}^{-1}\right)$ in tanks that showed high mortality (MB and $\left.\mathrm{CS}_{100}\right)$ than in tanks with low mortality (control and $\left.\mathrm{CS}_{5}\right)\left(10^{3}-10^{4} \mathrm{cfu} \mathrm{ml}^{-1}\right)$.

\section{Challenge C: Probiotic effect of Roseobacter 27-4 against V. anguillarum}

In rotifers enriched with algae (Isochrysis galbana) and Roseobacter 27-4, the levels of $V$. anguillarum were about $3 \times 10^{2} \mathrm{cfu} \mathrm{ml}^{-1}$, whereas in rotifers supplemented with $V$. anguillarum, the mean level was $2.5 \times 10^{3} \mathrm{cfu} \mathrm{ml}^{-1}$.

The accumulated survivals were lower in larvae fed rotifers enriched with V. anguillarum than in larvae fed non-enriched rotifers in all trials (Table 2). In larvae that received Roseobacter and Vibrio, survivals were intermediate or similar to those of controls. These relative differences also apply to growth of the larvae. The addition of Roseobacter significantly reduced the mortalities caused by V. anguillarum (Table 3). With respect to controls, survival in larvae challenged with both Roseobacter and V. anguillarum was 68\%, 
318 double than that of larvae challenged only with $V$. anguillarum. Accumulated mortality patterns were different among trials (Figure 3). However, the main differences in survivals between larvae infected, and those infected but treated with Roseobacter seem to occur preferentially after day 8 post hatching.

The bacterial counts were followed in the first challenge trial (Table 4). The level of culturable bacteria remained at $10^{6}-10^{7} \mathrm{cfu} \mathrm{ml}^{-1}$ water during the three trials. The level of Vibrionaceae in water and larvae during the experimental period were similar in all treatments, reaching a final level of about $10^{5} \mathrm{cfu} \mathrm{ml}^{-1}$ both in water and larvae. Roseobacter was identified in the water of the larval rearing tanks when rotifers with $V$. anguillarum and Roseobacter were added, at levels of about $10^{3}-10^{4} \mathrm{cfu} \mathrm{ml}^{-1}$, but not inside the larvae (Figure 4). The pathogen was isolated from water $\left(10^{3}-10^{4} \mathrm{cfu} \mathrm{ml}^{-1}\right)$ and larvae (higher than $10^{3} \mathrm{cfu}$

Immunohistochemistry

Øivind arrange this and modify. Make reference to ALL figures (in Fig. 4)!! Larvae to which cultures of Roseobacter 27-4 were added generally showed positive immunohistochemical staining of bacterial cells in the gut and intestinal lumen (Figure 4). The bacteria appeared to aggregate in the lumen, often forming relatively large particles composed of positively stained cells (Figure 4 e,f). Few bacteria were present on the gut and intestinal surfaces, and with single exceptions (see arrow in Figure $4 \mathrm{f}$ ) they did not display positive immunostaining. No bacterial cells could be visualised on gills and skin, and no positive immunohistochemistry was detected on these surfaces. As visualised in Figure $4 \mathrm{~d}$, small numbers of anti-Roseobacter 27-4 positive bacteria were also found in the gut and intestinal lumen following the addition of culture supernatant without bacterial addition. No indications of damages to larval gut or intestine, or other indications of harmful effects of the bacterial addition were detected in the larvae. Application of anti- $V$. anguillarum antibody caused positive (red) staining (Figure $4 \mathrm{c}$ ), indicating the presence of either this bacterium or serologically similar strains in the cultures. 


\section{Discussion}

The in vitro inhibitory activity of Roseobacter 27-4 was previously analysed by Hjelm et al. (2004a) in co-culture assays with the pathogens V. anguillarum and V. splendidus. It was demonstrated that both pathogens were inhibited when Roseobacter 27-4 reached high densities and that Roseobacter produced a soluble sulphur-containing anti-bacterial factor produced under stagnant conditions when the organism was also producing a brown pigment (Bruhn et al. 2005a).

The probiotic concept obviously requires that the bacterial strains are not pathogenic. In the present study, it was found that Roseobacter 27-4 did not cause any detrimental effects in turbot larvae when added supernatant-free to the water of the larval rearing tanks. However, a harmful effect was noticed when bacterial culture supernatant added at a high dose. The same dose of Marine Broth had similar effect so probably the nutrients in Marine Broth remaining in the supernatant promoted growth of opportunistic pathogenic bacteria, as Vibrionaceae, in the water of the rearing tanks and, consequently the high mortalities recorded

The usual way of entry for pathogens is orally, via prey (Muroga et al. 1987; Nicolás et al. 1989; Cahill, 1990; Bergh et al. 1994; Blanch et al. 1997; Ringø and Birkbeck, 1999), and therefore, we have studied in this work the delivery of Roseobacter $27-4$ via rotifers. It was noticeable that rotifers were not affected by high doses of bacterial supernatant, which makes the incubation of rotifers with Roseobacter 27-4 during long time enrichments possible. We also found less variability in the positive effect (survival) on larvae when Roseobacter 27-4 was delivered orally via rotifers rather by bath. Taking into account these facts, we consider bioencapsulation as a preferable way of delivery of Roseobacter 27-4 to larvae.

One of the reviewers said that this text (in red) is very speculative. Suggestions??? I think that we only give some ideas and explanations (to investigate in the future) but important. Vibrio anguillarum was better than Roseobacter strain 27-4 at colonizing rotifers and larvae. The presence of Roseobacter 27-4 in the intestinal lumen of larvae, but not in the gut or intestinal epithelium, indicates that the mode of action of this bacterium as a probiotic probably does not involve adhesion and colonisation of turbot larvae. Furthermore, it seems that the main protective function of the Roseobacter 27-4 could be more related to disallowing the proliferation or adhesion of pathogens, rather than adhering to distinct larval 
surfaces and colonising them. As seen in Challenge $\mathrm{C}$ (Table 3; Figure 3), the presence of Roseobacter reduced mortality but not $V$. anguillarum counts. Roseobacter might act by reducing the pathogenicity of $V$. anguillarum rather than diminishing the numbers of Vibrio. However, this hypothesis is contradictory with the findings of Hjelm et al. (2004a) in cocultures. These authors showed that presence of Roseobacter 27-4 (initial level of $10^{6}-10^{7}$ cfu $\mathrm{ml}^{-1}$ ) inhibited growth of $V$. anguillarum and $V$. splendidus during the first 5 days. The reduction of $V$. anguillarum concentration was seen when Roseobacter reached a concentration of $10^{9} \mathrm{cfu} \mathrm{ml}^{-1}$. Roseobacter 27-4 was present in the rotifers and appeared in the water, gut and intestinal lumen forming aggregates. V. anguillarum, when administrated to the larvae via infected rotifer, appeared in the epidermis of the larvae, which was severely affected, and in the gut of the larvae, associated to rotifers, but not on the intestinal epithelium (Ø. Bergh et al. unpublished results.). V. anguillarum has also been demonstrated to be taken up via the brush border of turbot larvae (Grisez et al. 1996). Therefore, Roseobacter 27-4, even not reducing the total counts of $V$. anguillarum in larvae, could perform the antagonistic effect at specific sites, and therefore improve survival of larvae. Further work should be done to elucidate this point.

In non-infected larvae, the presence of a low number of cells showing positive immunostaining following application of the anti- $V$. anguillarum antiserum could imply the natural presence of such bacteria. However, the absence of adhesion of immunolabelled bacteria to larval surfaces, and the generally normal appearance of the larvae indicate that this could be due to a cross-reaction with serologically similar bacteria. $V$. anguillarum is a well known pathogen to many species of fish, including turbot (Egidius, 1987; Myhr et al. 1991; Larsen et al. 1994; Toranzo et al. 1994) and it seems unlikely that the presence of such bacteria in significant amounts would not lead to pathological effects that would have been visible on the immunohistochemistry slides (Figure 4).

For turbot larvae challenged with $V$. anguillarum, the addition of Roseobacter 27-4 caused a reduction in mortalities. However, the mortality patterns during growth seemed to be different among trials as larval grow (Figure 3), but the causes are unknown at the present. On the other hand, microbiological analysis on the challenge systems showed little evidence of Roseobacter in the larval gut but high concentrations in the water (Table 4; Figure 4). This suggests that this probiotic does not colonise the turbot larval digestive tract but may act in the water or in surface biofilms from which it was isolated. Continuous additions (each 48-72 
419 h) are probably necessary to maintain a minimum level of Roseobacter $27-4$ in the culture 420 water and rotifers. Therefore, another practical approach to investigate in the future would be 421 the artificial production of a bio-film of such bacteria in the rearing system throughout the 422 year (Bruhn et al. 2005b).

The use of Roseobacter 27-4 has been shown to be safe in the hatchery live food environment and it fulfils the requirements of a probiotic, although, clearly, much remains to be done to optimise the quantity and frequency of addition of Roseobacter 27-4, in which case greater benefits should be expected.

\section{Acknowledgements}

This work was funded by the European Commission (Project PROBE, contract no. Q5RS2000-31457). We are grateful to Alicia Abalo and Rocío Rendo for technical support in the larval rearings and microbiological analyses. M. Pérez-Lorenzo was granted by the Xunta de Galicia (Spain), and to Drs. Jens Laurits Larsen and Jorunn Skjermo for supplying antisera. 


\section{References}

Austin, B., Stuckey, L.F., Robertson, P.A.W., Effendi, I., Griffith, D.R.W., 1995. A probiotic strain of Vibrio alginolyticus effective in reducing diseases caused by Aeromonas salmonicida, Vibrio anguillarum and Vibrio ordalii. J. Fish Dis. 18, 93-96.

Bano, N., Hollibaugh, J.T., 2002. Phylogenetic composition of bacterioplankton assemblages from the Arctic Ocean. Appl. Environ. Microbiol. 68, 505-518.

Bergh, Ø., 1995. Bacteria associated with early life stages of halibut, Hippoglossus hippoglossus L., inhibit growth of a pathogenic Vibrio sp. J. Fish Dis. 18, 31-40.

Bergh, Ø., Naas, K.E., Harboe, T., 1994. Shift in the intestinal microflora of Atlantic halibut (Hippoglossus hippoglossus) larvae during first feeding. Can. J. Fish. Aquat. Sci. 51, 18991903.

Bergh Ø., Hjeltnes, B., Skiftesvik, A.B., 1997. Experimental infection of turbot, Scophthalmus maximus and halibut Hippoglossus hippoglossus yolk sac larvae with Aeromonas salmonicida subsp. salmonicida. Dis. Aquat. Org. 29, 13-20.

Bergh, Ø., Vikanes, L., Makridis, P., Skjermo, J., Knappskog, D.H., Rødseth, O.M., 2001. Uptake and processing of a Vibrio anguillarum bacterin in Artemia franciscana measured by ELISA and immunohistochemistry. Fish Shellfish Immunol. 11(1), 15-22.

Blanch, A.R., Alsina, M., Simon, M., Jofre, J., 1997. Determination of bacteria associated with reared turbot (Scophthalmus maximus) larvae. J. Appl. Microbiol. 82, 729-734.

Boettcher, K.J., Barber, B.J., Singer, J.T., 2000. Additional evidence that juvenile oyster disease is caused by a member of the Roseobacter group and colonization of nonaffected animals by Stappia stellulata-like strains. Appl. Environ. Microbiol. 66, 3924-3930.

Boettcher, K.J., 2002. Characterization of Roseimarina crassostreae gen. nov., sp. nov., and the use of internal transcribed spacer (ITS) data to identify genotypes associated with mortalities of cultured oysters. 102nd annual meeting of the American Society for Microbiology, Salt Lake City, Utah.

Bruhn, J.B., Nielsen, K.F., Hjelm, M., Hansen, M., Bresciani, J., Schultz, S., Gram, L., 2005a. Ecology, inhibitory activity and morphogenesis of a potential marine fish larvae probiotic bacteria, Roseobacter strain 27-4. Appl. Environ. Microbiol. (submitted) 
Bruhn, J.B., Haagensen, J., Gram, L., 2005b. Real time PCR for detection and quantification of a fish probiotic Roseobacter in liquid culture and in biofilms. In preparation.

Cahill, M.M., 1990. Bacterial flora of fishes: A review. Microb. Ecol. 19, 21-41.

Egidius, E., 1987. Vibriosis: pathogenicity and pathology. A review. Aquaculture 67, 15-28.

Evensen, Ø., Rimstad, E., 1997. Immunohistochemical identification of infectious pancreatic necrosis virus in paraffin-embedded tissues of Atlantic salmon (Salmo salar). J. Vet. Diagn. Invest 2, 288-293.

FAO/WHO 2001. Evaluation of health and nutritional properties of powder milk and live lactic acid bacteria. Food and Agriculture Organization of the United Nations and World Health Organization expert consultation report. FAO, Rome, Italy.

García de la Banda, I., Chereguini, O., Rasines, I., 1992. Influencia de la adición de bacterias lácticas en el cultivo larvario del rodaballo (Scophthalmus maximus L.). Biol. Inst. Esp. Oceanogr. 8, 247-254.

Gatesoupe, F.J., 1991. The effect of three strains of lactic bacteria on the production rate of rotifers, Brachionus plicatilis, and their dietary value for larval turbot, Scophthalmus maximus. Aquaculture 96, 335-342.

Gatesoupe, F.J., 1994. Lactic acid bacteria increase the resistance of turbot larvae, Scophthalmus maximus, against pathogenic Vibrio. Aquat. Living Resour. 7, 277-282.

Gatesoupe, F.J., 1997. Siderophore production and probiotic effect of Vibrio sp. associated with turbot larvae, Scophthalmus maximus. Aquatic. Living Resour. 10: 239-246.

Gatesoupe, F.J., 1999. The use of probiotics in aquaculture. Aquaculture 180, 147-165.

Gildberg, A., Mikkelsen, H., Sandaker, E., Ringø, E., 1997. Probiotic effect of lactic acid bacteria in the feed on growth and survival of fry of Atlantic cod (Gadus morhua). Hydrobiologia 352, 279-285.

Gómez-Gil, B., Roque, A., Turnbull, J.F., 2000. The use and selection of probiotic bacteria for use in the culture of aquatic organisms. Aquaculture 191, 259-270.

Gram, L., Melchiorsen, J., Spanggaard, B., Huber, I., Nielsen, T.F., 1999. Inhibition of Vibrio anguillarum by Pseudomonas fluorescens AH2, a possible probiotic treatment of fish. Appl. Environ. Microbiol. 65, 969-973. 
Gram, L., Ringø, E., 2005. Prospects of fish probiotics. In: Holzapfel, W. and P. Naughton (eds) Microbial ecology of the growing animal. Elsevier. (Lone: full reference).

Grisez, L., Chair, M., Sorgeloos, P., Ollevier, F., 1996. Mode of infection and spread of V. anguillarum in turbot (Scophthalmus maximus) larvae after oral challenge through the live feed. Dis. Aquat. Org. 26, 181-187.

Grisez, L., Reyniers, J., Verdonck, L., Swings, J., Ollevier, F., 1997. Dominant intestinal microflora of sea bream and sea bass larvae, from two hatcheries, during larval development. Aquaculture 155, 387-399.

Hjelm, M., Bergh, Ø., Nielsen, J., Melchiorsen, J., Jensen, S., Duncan, H., Riaza, A., Ahrens, P., Birkbeck, H., Gram, L., 2004a. Selection and identification of autochthonous potential probiotic bacteria from turbot larvae (Scophtalmus maximus) rearing units. System. Appl. Microbiol. 27, 360-371

Hjelm, M., Riaza, A., Formoso, F., Melchiorsen, J., Gram, L., 2004b. Seasonal incidence of autochtonous antagonistic bacteria, Roseobacter spp. and Vibrionaceae, in a turbot larvae (Scophthalmus maximus) rearing system. Appl. Environ. Microbiol. 70, 7288-7298.

Huys, L., Dhert, P., Robles, R., Ollevier, F., Sorgeloos, P., Swings, J., 2001. Search for beneficial bacteria strains for turbot (Scophthalmus maximus L.) larviculture. Aquaculture 193, 25-37.

Kozasa, M., 1986. Toyocerin (Bacillus toyoi) as growth promoter for animal feeding. Microbiol. Aliment. Nutr. 4, 121-135.

Larsen, J.L., Pedersen, K., Dalsgaard, I., 1994. Vibrio anguillarum serovars associated with vibriosis in fish. J. Fish Dis. 17, 259-267.

Moran, M.A., González, J.M., Kiene, R.P., 2003. Linking a bacterial taxon to sulfur cycling in the sea: studies of the marine Roseobacter group. Geomicrobiol. J. 20, 375-388.

Munro, P.D., Barbour, A., Birkbeck, T.H., 1994. Comparison of the gut bacterial-flora of start-feeding larval turbot reared under different conditions. J. Appl. Bacteriol. 77, 560-566.

Muroga, K., Higashi, M., Keitoku, H., 1987. The isolation of intestinal microflora of farmed red seabream (Pagrus major) and black seabream (Acanthopagrus schlegeli) at larval and juvenile stages. Aquaculture 65, 79-88. 
Myhr, E., Larsen, J.L., Lillehaug, A., Gudding, R., Heum, M., Hastein, T., 1991. Characterization of Vibrio anguillarum and closely related species isolated from farmed fish in Norway. Appl. Environ. Microbiol. 57, 2750-2757.

Nicolas, J.L., Robic, E., Ansquer, D., 1989. Bacterial-flora associated with a trophic chain consisting of microalgae, rotifers and turbot larvae - influence of bacteria on larval survival. Aquaculture 153, 103-122.

Planas, M., Pérez-Lorenzo, M., Vázquez, J.A., Pintado, J., (2005). A model for the experimental infections with Vibrio (Listonella) anguillarum in first feeding turbot (Scophthalmus maximus L.) larvae under hatchery conditions. Aquaculture (in press).

Reitan, KI., Natvik, C.M., Vadstein, O., 1998. Drinking rate, uptake of bacteria and microalgae in turbot larvae. J. Fish Biol. 53, 1145-1154.

Ringø, E., Birkbeck, T.H., 1999. Intestinal microflora of fish larvae and fry. Aquacult. Res. 30, 73-93.

Ringø, E., Gatesoupe, F.J., 1998. Lactic acid bacteria in fish: a review. Aquaculture 160, 177203.

Ruiz-Ponte, C., Cilia, V., Lambert, C., Nicolas, J.L., 1998. Roseobacter gallaeciensis sp. nov., a new marine bacterium isolated from rearings and collectors of the scallop Pecten maximus. Int. J. Syst. Bacteriol. 48, 537-542.

Ruiz-Ponte, C., Samain, J.F., Sánchez, J.L., Nicolas, J.L., 1999. The benefit of Roseobacter species on the survival of scallop larvae. Mar. Biotechnol. 1, 52-59.

Selje, N., Simon, M., Brinkhoff, T., 2004. A newly discovered Roseobacter cluster in temperate and polar oceans. Nature $427,445-448$.

Shiba, T., 1991. Roseobacter litoralis gen. nov., sp. nov., and Roseobacter denitrificans sp. nov., aerobic pink-pigmented bacteria which contain bacteriochlorophyll $a$. Syst. Appl. Microbiol. 14, 140-145.

Shiba, T., 1992. The genus Roseobacter. In: The Prokaryotes, $2^{\text {nd }}$ ed. vol. III (eds. A. Balows, H.G. Trüper, M. Dworkin, W. Harder and K.-H. Schleifer). Springer-Verlag, New York, USA. 
543 Skov, M.N., Pedersen, K., Larsen, J.L., 1995. Comparison of pulsed-field gel electrophoresis, 544 ribotyping and plasmid profiling for typing of Vibrio anguillarum serovar O1. Appl. Environ. 545 Microbiol. 61, 1540-1545.

546 Toranzo, A.E., Barja, J.L., Devesa, S., 1994. An overview of the main infectious problems in 547 cultured turbot: present status and future necessities. EAS Spec. Pub. 22, 106-126.

548 Töbe, K., Ferguson, C., Kelly, M., Gallacher, S., Kedlin, K., 2001. Seasonal occurrence at a 549 Scottish PSP monitoring site of purportedly toxic bacteria originally isolated from the toxic 550 dinoflagellate genus Alexandrium. Eur. J. Phycol. 36, 243-256.

Verschuere, L., Rombaut, G., Sorgeloos, P., Verstraete, W., 2000. Probiotic bacteria as biological control agents in aquaculture. Microbiol. Mol. Biol. Rev. 64(4), 655-671. 


\section{Table 1:}

Challenge A - Changes with time in total bacteria and Roseobacter 27-4 in water (log cfu ml$\left.{ }^{1}\right)$ and turbot larvae $\left(\log\right.$ cfu larvae $\left.{ }^{-1}\right)$. Mean $(2$ parallel tanks $) \pm$ SD. SR: Single addition of Roseobacter 27-4 (day 3); CR: Continuous addition of Roseobacter 27-4 (days 3, 5 and 7); $\mathrm{CS}_{100}$ : Continuous addition of $100 \mathrm{ml}$ Roseobacter 27-4 free culture supernatant. ND: Not detectable.

\begin{tabular}{|c|c|c|c|c|c|c|}
\hline \multirow{9}{*}{$\begin{array}{l}\simeq \\
\text { II } \\
F \\
\ll \\
\mathbb{3}\end{array}$} & \multirow{2}{*}{ Total Bacteria } & Day & $\mathrm{C}$ & SR & $\mathrm{CR}$ & $\mathrm{CS}_{100}$ \\
\hline & & 3 & $6.50 \pm 0.08$ & $6.73 \pm 0.05$ & $6.77 \pm 0.02$ & $6.62 \pm 0.11$ \\
\hline & \multirow{7}{*}{ Roseobacter 27-4 } & 5 & $6.32 \pm 0.35$ & $6.25 \pm 0.10$ & $6.67 \pm 0.06$ & $6.13 \pm 0.76$ \\
\hline & & 7 & $6.32 \pm 0.47$ & $6.57 \pm 0.06$ & $6.58 \pm 0.14$ & $6.67 \pm 0.06$ \\
\hline & & 9 & $5.97 \pm 0.25$ & $5.93 \pm 0.11$ & $5.67 \pm 0.00$ & $6.83 \pm 0.00$ \\
\hline & & 3 & ND & $6.06 \pm 0.08$ & $6.19 \pm 0.16$ & ND \\
\hline & & 5 & ND & $5.98 \pm 0.85$ & $6.28 \pm 0.03$ & ND \\
\hline & & 7 & ND & $4.89 \pm 0.16$ & $6.00 \pm 0.00$ & ND \\
\hline & & 9 & ND & $3.72 \pm 0.17$ & $4.08 \pm 0.18$ & ND \\
\hline \multirow{6}{*}{ 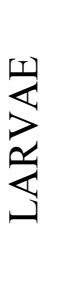 } & \multirow{6}{*}{ Roseobacter 27-4 } & 3 & $3.14 \pm 0.00$ & $2.67 \pm 0.00$ & $2.83 \pm 0.00$ & $2.71 \pm 0.00$ \\
\hline & & 6 & $5.22 \pm 0.38$ & $4.89 \pm 0.15$ & $5.21 \pm 0.54$ & $6.69 \pm 0.26$ \\
\hline & & 8 & $5.78 \pm 0.01$ & $5.13 \pm 0.04$ & $5.53 \pm 0.53$ & $4.85 \pm 0.23$ \\
\hline & & 3 & ND & $0.00 \pm 0.00$ & $0.00 \pm 0.00$ & ND \\
\hline & & 6 & ND & $2.69 \pm 0.26$ & $1.53 \pm 0.92$ & ND \\
\hline & & 8 & ND & $2.18 \pm 0.14$ & $3.97 \pm 0.61$ & ND \\
\hline
\end{tabular}




\begin{tabular}{|c|c|c|c|c|c|}
\hline \multirow[b]{2}{*}{ Trial } & \multirow[b]{2}{*}{ Day } & \multirow[b]{2}{*}{ Treatment } & \multicolumn{2}{|c|}{$\%$ survival } & \multirow{2}{*}{$\begin{array}{l}\text { Dry weight } \\
\mu \text { larva }^{-1}\end{array}$} \\
\hline & & & absolute & $\begin{array}{c}\text { relative to } \\
\text { control }\end{array}$ & \\
\hline \multirow[t]{3}{*}{$\mathrm{C} 1$} & 14 & Control & $34 \pm 13^{\mathrm{a}}$ & 100 & $337 \pm 13$ \\
\hline & 14 & Vibrio + Roseobacter & $35 \pm 4^{\mathrm{a}}$ & 103 & $505 \pm 66$ \\
\hline & 14 & Vibrio & $15 \pm 8^{\mathrm{a}}$ & 44 & $388 \pm 110$ \\
\hline \multirow[t]{3}{*}{$\mathrm{C} 2$} & 8 & Control & $29 \pm 1^{\mathrm{a}}$ & 100 & $40 \pm 3$ \\
\hline & 8 & Vibrio + Roseobacter & $17 \pm 0^{\mathrm{b}}$ & 52 & $41 \pm 3$ \\
\hline & 8 & Vibrio & $8 \pm 0^{\mathrm{c}}$ & 28 & $37 \pm 2$ \\
\hline \multirow[t]{3}{*}{$\mathrm{C} 3$} & 10 & Control & $32 \pm 1^{\mathrm{a}}$ & 100 & $121 \pm 0$ \\
\hline & 10 & Vibrio + Roseobacter & $17 \pm 1^{\mathrm{b}}$ & 53 & $122 \pm 10$ \\
\hline & 10 & Vibrio & $10 \pm 0^{\mathrm{c}}$ & 31 & $101 \pm 9$ \\
\hline
\end{tabular}

Table 2:

Challenge C - Survivals and final dry weights $\left(\mu \mathrm{g} \mathrm{larva}^{-1}\right)$ in the challenges performed to assess the probiotic effect of Roseobacter 27-4 against $V$. anguillarum. First feeding: day 3. Mean (2 parallel tanks) \pm SD. Different letters superscript mean significant differences (SNK test: $\mathrm{p}<0.05$ ) between treatments (ANOVA: $\mathrm{p}=0.470,0.001$ and 0.001 in challenges $\mathrm{C} 1, \mathrm{C} 2$, and $\mathrm{C} 3$, respectively). 


\section{Table 3:}

571 Challenge C - Effect of the delivery of Roseobacter 27-4 on the final survivals in turbot larvae 572 infected with Vibrio anguillarum (Pooled data from trials C1 - C3). Mean \pm SD. Different 573 letters superscript mean significant differences (SNK test: $p<0.05$ ) between treatments. $n$ : 574 number of trials.

575

\begin{tabular}{lccc}
\hline & & \multicolumn{2}{c}{$\%$ survival } \\
\cline { 3 - 4 } Treatment & $\mathrm{n}$ & absolute & relative to control \\
\hline Control & 3 & $32 \pm 3^{\mathrm{a}}$ & $100 \pm 0^{\mathrm{a}}$ \\
Vibrio + Roseobacter & 3 & $23 \pm 10^{\mathrm{a}}$ & $68 \pm 27^{\mathrm{a}}$ \\
Vibrio & 3 & $11 \pm 4^{\mathrm{b}}$ & $34 \pm 9^{\mathrm{b}}$ \\
\hline ANOVA-p & & 0.018 & 0.008
\end{tabular}




\section{Table 4:}

Challenge $\mathrm{C}-$ Changes on the microflora in water (Log cfu.ml ${ }^{-1}$ ) and larvae (Log cfu.larva ${ }^{-1}$ ) in Trial C1. Mean (2 parallel tanks) \pm SD. VR: larvae were fed with rotifers enriched with Roseobacter 27-4(days 3, 5 and 7), with rotifers enriched with V. anguillarum (days 4, 6 and 8); V: larvae fed on rotifers enriched with V. anguillarum (days 4, 6 and 8). ND: Not detectable.

\begin{tabular}{|c|c|c|c|c|c|}
\hline \multirow{13}{*}{\begin{tabular}{l}
\multicolumn{1}{c}{} \\
I \\
$F$ \\
$\ll$ \\
3
\end{tabular}} & \multirow{5}{*}{ Total Bacteria } & Day & Control & VR & $\mathrm{V}$ \\
\hline & & 3 & $5.95 \pm 0.16$ & $6.01 \pm 0.09$ & $6.29 \pm 0.05$ \\
\hline & & 5 & $6.45 \pm 0.07$ & $6.30 \pm 0.08$ & $6.37 \pm 0.07$ \\
\hline & & 7 & $6.45 \pm 0.04$ & $6.34 \pm 0.06$ & $6.39 \pm 0.00$ \\
\hline & & 9 & $6.78 \pm 0.03$ & $6.78 \pm 0.11$ & $6.67 \pm 0.06$ \\
\hline & \multirow[t]{4}{*}{ Roseobacter 27-4 } & 3 & ND & $3.15 \pm 0.21$ & ND \\
\hline & & 5 & ND & $4.15 \pm 0.21$ & ND \\
\hline & & 7 & ND & ND & ND \\
\hline & & 9 & ND & $2.74 \pm 0.37$ & ND \\
\hline & \multirow{4}{*}{ V. anguillarum } & 3 & ND & ND & ND \\
\hline & & 5 & ND & $3.94 \pm 0.14$ & $4.00 \pm 0.00$ \\
\hline & & 7 & ND & $3.00 \pm 0.06$ & $2.42 \pm 0.60$ \\
\hline & & 9 & ND & $3.94 \pm 0.14$ & $3.66 \pm 0.26$ \\
\hline \multirow{12}{*}{ 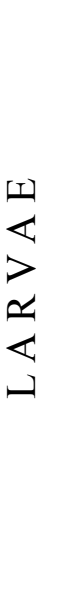 } & \multirow[t]{4}{*}{ Total Bacteria } & 3 & $2.62 \pm 0.02$ & $3.83 \pm 0.01$ & $2.72 \pm 0.07$ \\
\hline & & 5 & $4.07 \pm 0.82$ & $4.07 \pm 0.03$ & $4.27 \pm 0.45$ \\
\hline & & 7 & $5.23 \pm 0.04$ & $4.85 \pm 0.04$ & $5.01 \pm 0.54$ \\
\hline & & 9 & $5.58 \pm 0.21$ & $5.40 \pm 0.13$ & $5.52 \pm 0.39$ \\
\hline & \multirow[t]{4}{*}{ Roseobacter 27-4 } & 3 & ND & $\mathrm{ND}$ & ND \\
\hline & & 5 & ND & ND & ND \\
\hline & & 7 & ND & ND & ND \\
\hline & & 9 & ND & ND & ND \\
\hline & \multirow[t]{4}{*}{ V. anguillarum } & 3 & ND & ND & ND \\
\hline & & 5 & ND & $2.92 \pm 1.05$ & $1.61 \pm 2.28$ \\
\hline & & 7 & ND & $1.57 \pm 2.21$ & $2.68 \pm 0.71$ \\
\hline & & 9 & ND & $4.19 \pm 1.01$ & $1.59 \pm 2.25$ \\
\hline
\end{tabular}




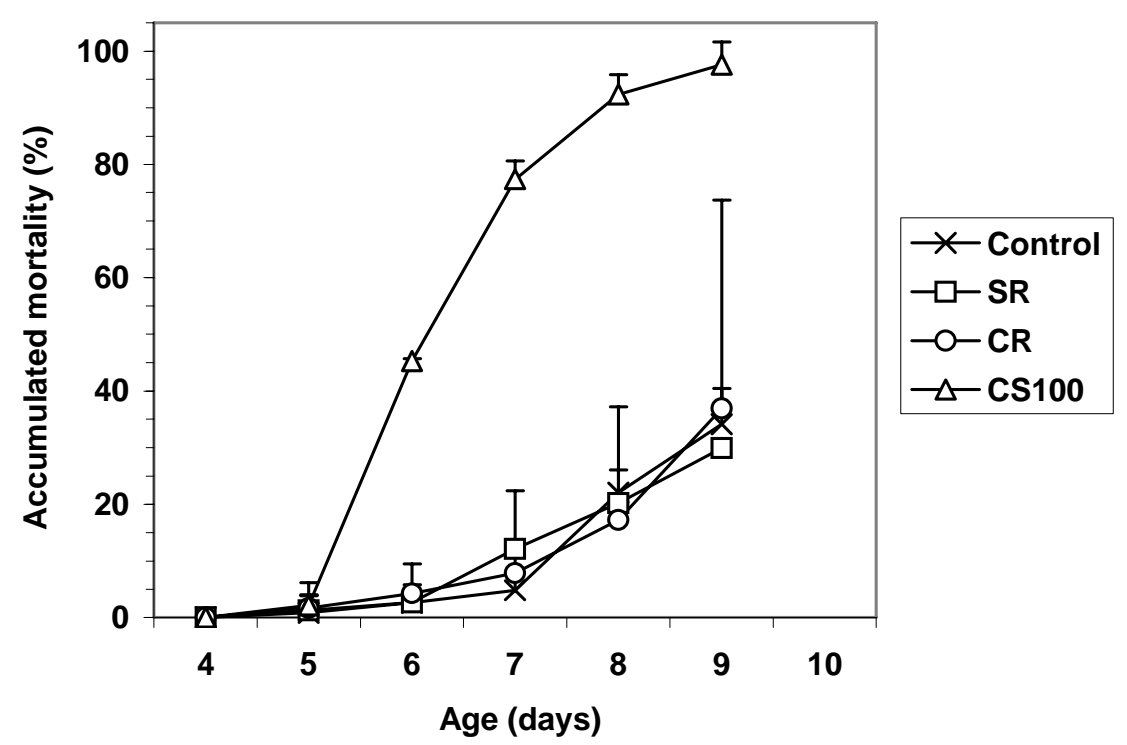

Figure 1:

590 Challenge A - Accumulated mortality in turbot larvae from challenge A. Mean (2 parallel 591 tanks) \pm SD. SR: Single addition of Roseobacter 27-4 (day 3); CR: Continuous addition of 592 Roseobacter 27-4 (days 3, 5 and 7); $\mathrm{CS}_{100}$ : Continuous addition of $100 \mathrm{ml}$ Roseobacter 27-4 593 free culture supernatant. 


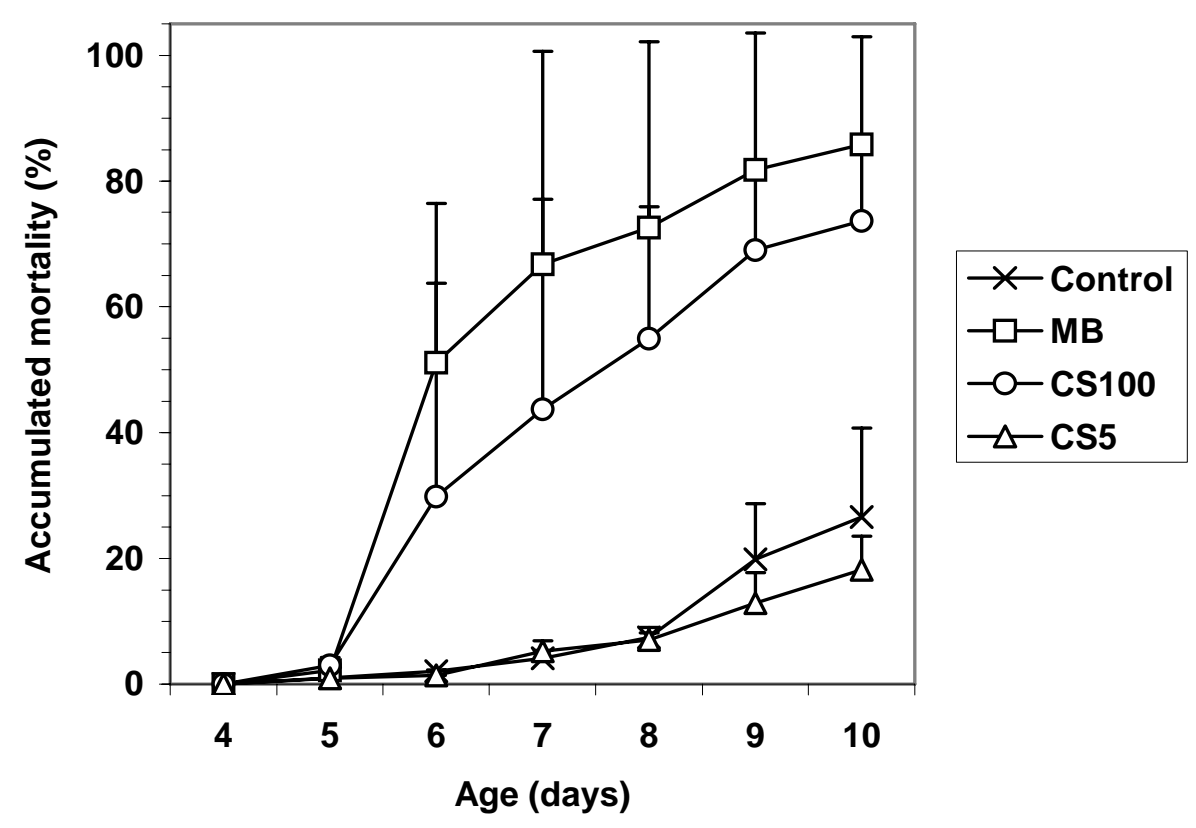

Figure 2:

601 Challenge B - Accumulated mortalities in turbot larvae in the presence of marine broth and 602 supernatant of Roseobacter cultures. Mean (2 parallel tanks) \pm SD. MB: Addition of $100 \mathrm{ml}$ 603 of Marine Broth to the water; $\mathrm{CS}_{100}$ and $\mathrm{CS}_{5}$ : Continuous addition of 100 and $5 \mathrm{ml}$ 604 Roseobacter 27-4 free culture supernatant, respectively. 

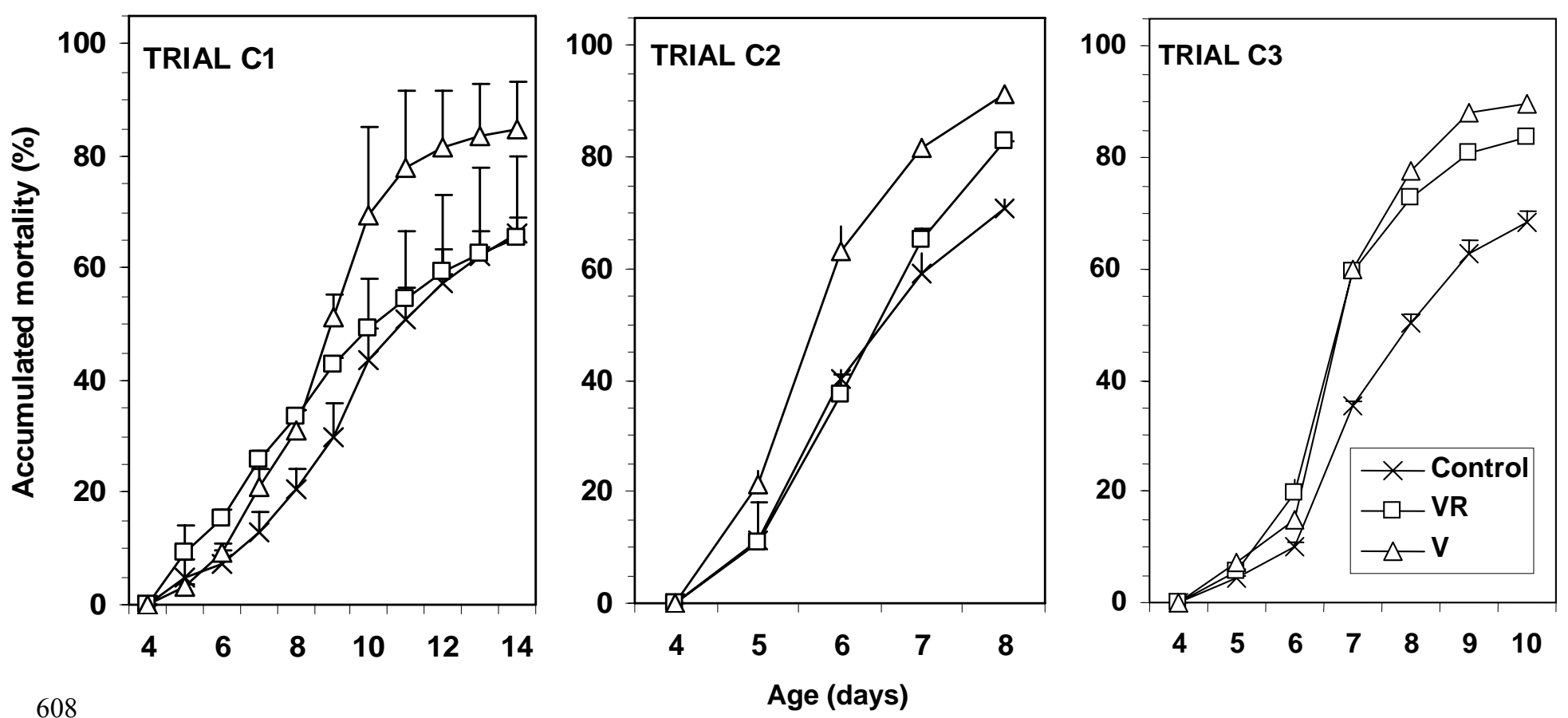

$612 \quad$ Figure 3:

613 Challenge C - Accumulated mortalities in turbot larvae from Trials C1, C2 and C3. Mean (2 614 parallel tanks) \pm SD. VR: larvae were fed with rotifers enriched with Roseobacter 27-4(days 6153,5 and 7), with rotifers enriched with $V$. anguillarum (days 4, 6 and 8) and with non616 enriched rotifers (days 9 and 10); V: larvae fed on rotifers enriched with V. anguillarum (days 6174,6 and 8). 


\section{4 - SUBMITTED ON FILE}

\section{Figure 4:}

Oivind: can you rearrange the text (from a to f)!!! Immunohistochemistry of turbot larvae. Primary antibodies against Roseobacter 27-4 (a,b,d,e,f) and V. anguillarum (c). Larva from control group to which no bacterial strain was added is shown in (a). Note the presence of particles (arrow) in the lumen of the gut not stained by the immunohistochemical protocol. Larvae from groups added continuously Roseobacter 27-4 are shown in b, c, e and f. s b, e and f all displayed positively stained (red) bacterial cells (arrow) in the lumen of the larval gut following application of the anti-Roseobacter 27-4 primary antibody. Fig. d nor defined!!!! 